Annales Missiologici Posnanienses t. 19 (2014), s. 79-89

DOI: $10.14746 / \mathrm{amp} .2014 .19 .3$

ACHIEL PEELMAN

Faculty of Theology, Saint Paul University, Ottawa

\title{
Bimaadiziwin. Native American Approaches to the Mystery of Life
}

Native American spirituality represents a perennial source of wisdom which is still very much alive today. What can we learn from this spirituality for a better understanding and experience of the mystery of life? Life occupies a central place in this spirituality just like in traditional African cultures. But Native American peoples do not offer us theoretical definitions of life. Aboriginal languages are not object-oriented as are European languages. They are verb or action-oriented and speak to what we do rather than what we are. ${ }^{1}$ This is why I have structured this article around the Ojibway concept of Bimaadiz$i$ win. This concept, which is difficult to translate, expresses the fullness of life, the development of harmonious relationships, a well-balanced life style, and good health. ${ }^{2}$ In the first part of this article I will present three major aspects of traditional Native American spirituality related to life. In the second part I will briefly expose the importance of the "Spirit-World" for aboriginal peoples. Part three deals with the Medicine Wheel, a healing process which represents the holistic nature of Native spirituality per excellence. Most of these reflections are inspirited by my personal experience of this spirituality in the field. During the 1980s, I worked with several medicine-men and was invited to do the Vision Quest four years in a row under the guidance of Cree shamans and elders in Alberta. ${ }^{3}$

\footnotetext{
${ }^{1}$ See D. McPherson, A Definition of Culture. Canada and the First Nations, in: Native American Religious Identity. Unforgotten Gods, ed. J. Weaverm, Maryknoll 1998, p. 77-98.

${ }^{2}$ A.I. Hallowell, Ojibwa Ontology, Behavior, and World View, in: Contributions to Anthropology. Selected Papers of A. Irving Hallowell, Chicago 1976, p. 383-384.

${ }^{3}$ See A. Peelman, Christ Is a Native American, Eugene 1995 (New Edition); idem, L'Esprit est amérindien. Quand la religion amérindienne rencontre le christianisme, Montréal 2004.
} 


\section{Native American Spirituality and the Fullness of Life}

Native American spirituality offers us three major insights related to the mystery of human life: vision, harmonious or inclusive relationships, and space.

\section{No Bimaadiziwin (Fullness of Life) without Vision}

Ojibway historian Basil Johnson states: "No man begins to be until he has received his vision." ${ }^{4}$ This is why in the past adolescent boys were sent into the woods to quest for a vision. When they returned from the woods the Elders would interpret their vision and give them Indian names symbolizing the basic orientation of their lives. The successful accomplishment of the ritual, often through the gift of a spiritual power associated with an animal Spirit, allowed the young person to enter fully into his community and into the Native American spiritual universe. Generally speaking, this ritual would not apply to young girls, because they had already a unique place in their community as future mothers in close connection with Mother Earth. They were initiated by the women Elders or Medicine women.

While the Vision Quest is not imposed any more on adolescent boys, many Native communities practice the Name-Giving ceremony. When the boys and girls reach the age of puberty, their parents may ask an Elder to "dream" an Indian name for their children. This Indian name does not replace the Christian name but has a symbolic meaning for their life journeys and their future places in the community. But I still met with parents, especially in Alberta, who supported the fact that their young children would freely go into the woods, especially during the night, with the hope that they may encounter their animal guides. For these parents, even though they became Christians, traditional spiritualty remained very important and would never be taken away from them.

Today, the Vision Quest is practiced by adult women and men often to restore their lives after violent or destructive experiences. It may also be part of a Native retreat to reflect on life or relationships. The Vision Quest is one of the most important rituals practiced by many Aboriginal peoples in North America according to their own local and oral traditions. ${ }^{5}$ The Lakota, for example, call it hanbleciya, literally, "calling out for a dream." ${ }^{16}$ Others use the

${ }^{4}$ B. Johnson, Ojibway Heritage. The Ceremonies, Rituals, Songs, Dances, Prayers and Legends of the Ojibway, Toronto 1967, p. 119.

${ }^{5}$ See Ch. Vecsey, Traditional Ojibwa Religion and Its Historical Changes, Philadelphia 1983; A. Amiotte, Eagles Fly Over, in: Native American Traditions. Sources and Interpretations, ed. S. Gill, Delmont 1983, p. 90-114.

${ }^{6}$ R. Erdoes, Crying for a Dream, Santa Fe 1990, p. 24-28. 
term "Vigil ritual." The ritual usually takes place in an isolated area. It consists of a total fast (no food or water) lasting for an average of four nights and three days. The faster meditates from sunset to sunrise, often near a small campfire, and rests during the day without leaving the ritually-prepared location. The vision one receives is at the same time a gift and a call (a vocation). It is the gift of the spiritual powers we need to fulfill our life and to "walk in balance" on the road indicated by the vision. We truly need these powers, because we will always be "incomplete" or "unfinished" beings in search for perfection or fulfillment. But the gifts one receives must also be shared with the members of one's community, otherwise they may become ineffective. The purpose of the total fast is also to become aware of the obstacles we encounter during our life journey and to eliminate them. The Vision Quest reflects one of the most important challenges of human existence. As long as we do not know who we are, that is, as long as we lack vision, we cannot live in communion with others and develop our life harmoniously.

From an Aboriginal Elder I met during my own Vision Quests I also learned that there is a major difference between visions and ideas. Visions are gifts we receive gracefully. Ideas are products of our mind. Westerners are obsessed by ideas and theories. We produce them in our schools, universities and workshops, day after day. But do they really help us to develop our spiritual life now that we experience rapid and sometimes disturbing transformations especially in the context of globalization? Native spirituality reminds us also that life is fundamentally a gift. We are not the creators of our own life. We receive it. But there is no gift or donation without a reciprocal donation. For example, when Innu hunters take the life of a caribou, they will thank the animal for the gift of its life. They will treat its bones with great respect. In doing so, they perform a spiritual ritual of counter-donation. The Vision Quest has a profound anthropological and theological meaning for Native peoples who have maintained and developed the ritual for centuries. ${ }^{8}$

\section{No Bimaadiziwin (Fullness of Life) without Harmonious and All-inclusive Relations}

Native American spirituality presents itself as a "communitarian" journey. Especially in the post-colonial context, it wants to get away from the "individualistic" perspective which largely dominated western modernity and Christi-

\footnotetext{
${ }^{7}$ A. Smith, Walking in Balance, in: Native American Religious Identity, ed. J. Weaver, p. 178$-198$.

${ }^{8}$ A. Hultkrantz, Tribal and Christian Elements in the Religious Syncretism Among the Shoshoni Indians in Wyoming, in: Belief and Worship in Native North America, ed. Ch. Vecsey, Syracuse 1981, p. 212-234.
} 
anity. Jace Weaver (Cherokee), professor at Yale University, demonstrates the need for Native American theology to make the passage from an "I-hermeneutics" to a "We-hermeneutics." 9 The major task of this We-hermeneutics concerns the reconstruction of Aboriginal identity by the re-activation of traditional values. GeorgeTinker (Osaga Nation) develops a theology of reciprocity, harmony, and balance. ${ }^{10}$ But for many Native theologians or philosophers Indian "inter-relationships" are not limited to human beings alone. They include all living elements in the universe. In fact, we live in a world that is "more than human." 11 This is why some Native authors apply the notion of "personhood" not only to humans but also to all other living elements in the universe: animals, trees, rocks, plants, fish, mountains, and rivers! This has important implications for the relationship between humans and other living beings. Others are not simply "objects" to explore and to dominate but "living beings" to be respected.

Post-colonial Native spirituality makes an effort to get out of a field of interpretation centered on the human being alone. We have much to learn from all the other beings around us. We need them for the full realization of our life, because we are the most "vulnerable" among all living beings! This is what an Elder shared with me during my first Vision Quest in the large circular valley of the Kootenay Plains surrounded by the beautiful Rocky Mountains, a sacred place where Native peoples have come together for major ceremonies since time immemorial.

\section{No Bimaadiziwin (Fullness of Life) without Vital Space}

The third insight offered by Native American spirituality concerns the priority of space over time. Vine Deloria, Jr, the late dean of American Indian academics, who is considered to be the initiator of Amerindian-Christian theology, was the first to note this in his milestone book, God is Red. A Native View of Religion, published in 1973. ${ }^{12}$ He compares the Native American worldview with the Christian worldview. He notes, particularly, how Christianity radically values the temporal or historical dimension of human existence. This is why progress, development, evolution, and exploitation characterize so much

${ }^{9}$ J. Weaver, From I-Hermeneutics to We-Hermeneutics, in: Native American Religious Identity, op.cit., p. 1-25.

${ }^{10}$ G. Tinker, American Indian Liberation. A Theology of Sovereignty, Maryknoll 2008.

${ }^{11}$ D. Abram, The Spell of the Sensuous. Perception and Language in a More-Than-Human World, New York 1996.

${ }^{12}$ V. Deloria, Jr, God Is Red. A Native View of Religion. 30 $0^{\text {th }}$ Anniversary Edition, Golden [Colorado] 2003. Vine Deloria obtained a degree in theology because he first planned to become an Episcopalian minister like his father. 
of the Western mentality. Native American spirituality, on the contrary, greatly values the notion of space. Like African traditional religions, it also affirms the sacredness of the entire universe. ${ }^{13}$

Deloria does not deny the importance of historicity, which is one of the main characteristics of western modernity. But he calls for balance between historicity and spatiality. Spatiality is also closely associated with reciprocity. The Native American concept of reciprocity is fundamental to all human efforts to develop a world-balancing and harmonious environment as symbolized by the circle, a central element of Native American spirituality and ritual life. ${ }^{14}$ Finally, it is also important to note that Native American spirituality strongly affirms the mystical dimension of human existence as well as the importance of contemplation and meditation. This was often gently communicated to me by the Elders who guided me in my Vision Quests. In fact, the Vision Quest is fundamentally a contemplation ritual.

\section{The Spirit-World and the Spiritual Powers}

For the Native American and other traditional peoples life is fundamentally a mystery because everything is spiritually interconnected. For them the universe is an "animated" universe or a "meaningful" universe where the Spirits or the (spiritual) Powers are omnipresent. ${ }^{15}$ Many Native persons, even those who are deeply influenced by Western culture, continue to believe that these Powers have a real impact on their personal lives and on their communities. Michael Pomedli (professor emeritus of Saint Thomas More College, Saskatchewan) recently published a well-documented study, entitled Living With Animals, on the spiritual powers of the Ojibway Medewiwin or Grand Medicine Society, illustrating this fact. ${ }^{16}$ Obviously, this dimension of the Native American vision of life is often highly disturbing for our Western mentality. We quickly ask: Is all this real?

It was certainly real for one of my spiritual guides, Joseph Couture, a Cree medicine-man, notwithstanding the fact that he possessed a doctorate in psychology! I participated in many of his healing rituals with the Sacred Pipe where he used to call upon the spiritual Powers. I even assisted him once in an

\footnotetext{
${ }^{13}$ See, for example, L. Magesa, What is Not Sacred? African Spirituality, foreword by Benezet Bujo, Maryknoll 2013.

${ }^{14}$ See C.S. Kidwell, H. Noley, G. Tinker, A Native American Theology, Maryknoll 2001. Chapter 2: "Creation. Balancing the World for Seven Generations."

${ }^{15}$ A. Peelman, Christ Is A Native American..., op.cit., p. 50-55.

${ }^{16}$ M. Pomedli, Living With Animals. Ojibwe Spiritual Powers, Toronto 2014.
} 
exorcism ritual. It was also real for Don Goodwin, medicine-man and ordained Catholic deacon from the Grand Rapids diocese (Michigan), who invited me to participate in a healing Sweat Lodge ritual which he organized for a group of Native men in Thunder Bay (Ontario) in 1991. Several of these men had been affected by very destructive experiences and were searching for healing. At the beginning of the ritual, the presiding medicine-man evoked the Spirits or the "Winds" of the four cardinal directions of the universe who were present in the Lodge to participate in the ritual. But he also called upon Jesus, the Son of the Creator, who occupies a unique place among all the spiritual Powers. I have often met with Native persons who do not only believe that Jesus was a great shaman or medicine-man but that he was the Medicine or spiritual Power par excellence.

Native peoples dispose of a great variety of terms to name these Powers. For example, for the Dene Tha in Alberta, Echint'e means "Power"; a person who has met with his animal protector or guide is called dene wonlin edadihi, someone who knows an animal. ${ }^{17}$ The Lakota of Rose Bud Reserve (South Dakota) know many spirits: protector spirits, spirits who can predict the future, but also Trickster spirits who can disorganize one's life and even cause great harm. ${ }^{18}$ The majority of the names given to these Powers indicate, however, that the Native peoples are more preoccupied with the functional nature of the Powers than with their ontological status.

Many Natives consider the Spirit-World as a kind of "Middle World" between their own environment and the transcendent Absolute Being who is not directly accessible. We encounter similar situations in Africa and Asia. ${ }^{19}$ The Mennonite missionary Paul Hiebert, who was born and worked in India, noted that the Christian Churches tried everything to eliminate this Spirit-World from the life of their indigenous converts but without success. We see the same thing in Africa as well as in Native North America where many Christians make frequent passages between their new Christian faith and their traditional beliefs. ${ }^{20}$ To deal with this situation and to foster the development of a holistic theology that respects the religious or cultural traditions of the Aboriginal converts to Christianity, Hiebert offers an analytical framework composed

17 J.-G. Goulet, Visions et conversions chez les Déné Tha. Expériences religieuses chez un peuple autochtone converti, « Religiologiques » 6 (1992), p. 147-182.

${ }^{18}$ W. Stolzman, The Pipe and Christ. A Christian-Sioux Dialogue, Chamberlain [South Dakota] 1986.

${ }^{19}$ V. Naipul, The Masque of Africa. Glimpses of African Belief, New York 2010; S. Ellis, G. Ter Haar, World of Power. Religious Thought and Political Practice in Africa, New York 2004.

${ }^{20}$ See A. Shorter, Jesus and the Witchdoctor. An Approach to Healing and Wholeness, LondonMaryknoll 1985; The Crossing of Two Roads. Being Catholic and Native in the United States, ed. M.Th. Archambault, M. Thiel, Ch. Vecsey, Maryknoll 2003. 
of two logics: the "mechanical logic" and the "organic logic."21 "Mechanical logic" seeks to understand what happens in the world and in our lives on the basis of scientific, well-proven causes, good or bad. These causes do not have an ethical dimension in themselves. They allow us to better control what we experience, but they certainly do not explain everything! "Organic logic," on the contrary, seeks to understand what happens in the world and in our lives by reflecting on the spiritual relationships between all the living beings of the universe. This logic also has its limits, because life is basically a mystery. To deal more adequately with the mystery of life, therefore, we need to balance mechanical and organic logic or develop an "organic-mechanical continuum." While "mechanical logic" imposes itself almost exclusively on the modern, secularized Western mind, Native American spirituality and other traditional cultures remain excellent examples of "organic logic." The dialogue that is now unfolding between traditional Native spirituality and the Christian faith must respect and integrate these two logics for the well-being or the Bimaadiziwin of all.

\section{The Symbolic Teachings of the Medicine Wheel}

The Medicine Wheel is a very old graphic symbol used by many Native peoples in North and South America. It is used as a therapeutic tool for explaining the various dimensions of human existence and their relationship with each other. It is the most powerful expression of the holistic nature of Native spirituality. The Medicine Wheel is designed as a perfect circle divided in four segments by a cross. It is a sort of "mirror" in which we see ourselves like we truly are with our strengths and weaknesses. The four segments or points symbolize all the visible and invisible relationships we need to realize our $B i$ maadiziwin. According to Ojibway Medicine-Women and registered nurse, Rosella Kinoshemeg, the therapeutic quality of the Medicine Wheel consists in the capacity to locate oneself in one of the four segments of the circle while visualizing at the same time the multiple links with the other three segments to achieve balance and harmony. ${ }^{22}$

Native Elders use different names for the ancient symbol of the Medicine Wheel: the four grandfathers, the four winds, the four cardinal directions, and so on. Each direction offers us a certain number of "gifts" and represents basic

${ }^{21}$ P. Hiebert, The Flaw of the Excluded Middle, in: Landmark Essays in Mission and World Christianity, ed. R. Gallagher, P. Hertig, Maryknoll 2009, p. 179-189.

${ }^{22}$ R. Kinoshemeg, Healing our Bodies and Minds. [The "New Sun" Lecture Series on Reconciliation and Healing Among Aboriginal Peoples], Ottawa November 18, 1998. 
values, attitudes or orientations we need to realize our life in communion with all other forms of life. But nothing happens unless we freely start a healing journey around the circle and evaluate our relationships. What are these relationships?

The following list of relationships is based on a study prepared by a group of Native researchers at the University of Lethbridge, Alberta. ${ }^{23}$ The four points in the circle represent the four cardinal directions of the universe (North, East, South, and West) with their specific energies and Powers. They teach us that the four symbolic races (White, Red, Yellow, and Black) are all part of the same human family. All are sisters and brothers living on the same Mother Earth. The circle represents the four elements of the physical universe: fire, earth, air and water. All must be respected equally for their gift of life. The circle symbolizes the four aspects of human potentiality: the physical, the emotional, the mental and the spiritual, all converging at the intersection within the human person, known as the will. It represents the four aspects of human knowing: action, reflection, interpretation, and understanding, mediated by the world-shaping power of belief and vision. The circle also represents the four "hills" of human life: childhood, youth, adulthood and old age.

In my personal use of the Medicine Wheel, I always start in the East and focus on the value of "creativity." Every sunrise is like a new creation, a new starting point, an invitation to creative actions. The South permits me to evaluate the fruits of these actions, to give thanks to the Creator for all the gifts I receive. Here the main value is "generosity." The West reminds me of the importance of "quietness" and rest but also of the "fragility" of my existence, symbolized by the darkness of the night after sunset. The North symbolizes "courage" and "perseverance," because once I have reached the North I have to start all over again.

Finally, it may be important to note that the Medicine Wheel is not exclusively used by the so-called "traditionalists:" those Native persons who never adopted the Christian faith or those who, after they became Christian, returned to their own religious traditions because of the past and present tensions between their culture and Christianity. It is also used by Catholics such as Rosella Kinoshemeg, who is very involved in the Catholic community on Manitoulin Island, Ontario. For her, it is a powerful tool for reconciliation and peacemaking. ${ }^{24}$ Mohawk Sister Kateri Mitchel referred to the Medicine Wheel in a conference presented during a Colloquium organized by the Pontifical

${ }^{23}$ See J. Bopp and others, The Sacred Tree, Lethbridge 1984.

${ }^{24}$ A. Peelman, The Spiritual Foundations of Peacemaking Among Canada's First Nations Peoples, in: Pontifical Council for Interreligious Dialogue, Resources for Peace in Traditional Religions. Acts of the Colloquium. Rome, 12-15 January 2005 [manuscript], Vatican City 2006, p. 175-188 . 
Council for Interreligious Dialogue in Rome, 2005. ${ }^{25}$ She mentioned that the Medicine Wheel had become a powerful instrument of spiritual, emotional, physical, and mental healing for many members of the Tekakwitha Conference, the North American organization of Catholic Natives, which began in 1939. During its annual meetings, especially since the visit of Pope John Paul II to North America in 1987, this organization has made tremendous efforts to promote dialogue between traditional Native spirituality and Christianity. Pope John Paul II then strongly encouraged Native Peoples "to share the richness of our spirituality and culture with the Universal Church." In this article I have indeed tried to show that these peoples do offer us profound insights for deepening our understanding of the great mystery of life.

\section{SUMMARY}

Structured around the Ojibwe concept Bimaadiziwin (fullness of life), this study demonstrates how Native American Spirituality contributes to a deeper approach of the mystery of life by its focus on vision, all-inclusive relationships and space. All this is intimately related to the "Spirit world" and symbolized in a unique way by the Medicine Wheel ritual.

Keywords: Native American Spirituality, Vision Quest, Spirit-World, Medicine Wheel, All-Inclusive Relationships, Fullness of Life

Slowa kluczowe: duchowość indiańska, relacje inkluzywne, pełnia życia, vision quest, medicine wheel

\section{BIBLIOGRAPHY}

Abram D., The Spell of the Sensuous. Perception and Language in a More-Than-Human World, New York: Vintage Books, 1996.

Amiotte A., Eagles Fly Over, in: Native American Traditions. Sources and Interpretations, ed. S. Gill, Delmont: Wadsworth Publications, 1983, p. 90-114.

Bopp J., Bopp M., Brown L., Lane P. Jr., The Sacred Tree, Lethbridge: Four Worlds Development Press, 1984.

Deloria V., Jr, God Is Red. A Native View of Religion. 30 ${ }^{\text {th }}$ Anniversary Edition, Goldon, Colorado: Fulcrum Publishing, 2003.

${ }^{25}$ K. Mitchell, Tekakwitha Conference: Affirming our Faith as Native American Catholics Under the Protection of Blessed Kateri Tekakwitha, in: Pontifical Council for Interreligious Dialogue, Resources for Peace in Traditional Religions..., op.cit., p. 139-144. 
Ellis S., Ter Haar G., World of Power. Religious Thought and Political Practice in Africa, New York: Oxford University Press, 2004.

Erdoes R., Crying for a Dream, Santa Fe: Bear \& Company, 1990.

Goulet J.-G., Visions et conversions chez les Déné Tha. Expériences religieuses chez un peuple autochtone converti, « Religiologiques » 6 (1992), p. 147-182.

Hallowell A.I., Ojibwa Ontology, Behavior, and World View, in: Contributions to Anthropology. Selected Papers of A. Irving Hallowell, Chicago: University of Chicago Press, 1976, p. 357-390.

Hiebert P., The Flaw of the Excluded Middle, in: Landmark Essays in Mission and World Christianity, ed. R. Gallagher, P. Hertig. Maryknoll: Orbis Books, 2009, p. 179-189.

Hultkrantz A., Tribal and Christian Elements in the Religious Syncretism Among the Shoshoni Indians in Wyoming, in: Belief and Worship in Native North America, ed. Ch. Vecsey, Syracuse: University of Syracuse Press, 1981, p. 212-234.

Johnson B., Ojibway Heritage. The Ceremonies, Rituals, Songs, Dances, Prayers and Legends of the Ojibway, Toronto: McLelland and Stewart, 1967.

Kidwell C.S., Noley H., Tinker G., A Native American Theology, Maryknoll: Orbis Books, 2001.

Kinoshemeg R., Healing our Bodies and Minds. [The "New Sun" Lecture Series on Reconciliation and Healing Among Aboriginal Peoples], Ottawa: Saint Paul University, November 18, 1998.

Magesa L., What is Not Sacred? African Spirituality, foreword by Benezet Bujo, Maryknoll: Orbis Books, 2013.

McPherson D., A Definition of Culture. Canada and the First Nations, in: Native American Religious Identity. Unforgotten Gods, ed. J. Weaver, Maryknoll: Orbis Books, 1998, p. 77-98.

Mitchell K., Tekakwitha Conference: Affirming our Faith as Native American Catholics Under the Protection of Blessed Kateri Tekakwitha, in: Pontifical Council for Interreligious Dialogue, Resources for Peace in Traditional Religions. Acts of the Colloquium. Rome, 12-15 January 2005 [manuscript], Vatican City 2006, p. 139-144.

Naipul V., The Masque of Africa. Glimpses of African Belief, New York: Vintage Books, 2010.

Peelman A., Christ Is a Native American, Eugene, Oregon: Wipf \& Stock, 1995 (New Edition).

Peelman A., L'Esprit est amérindien. Quand la religion amérindienne rencontre le christianisme, Montréal: Médiaspaul, 2004.

Peelman A., The Spiritual Foundations of Peacemaking Among Canada's First Nations Peoples, in: Pontifical Council for Interreligious Dialogue, Resources for Peace in Traditional Religions. Acts of the Colloquium. Rome, 12-15 January 2005 [manuscript], Vatican City 2006, p. 175-188 .

Pomedli M., Living With Animals. Ojibwe Spiritual Powers, Toronto: University of Toronto Press, 2014.

Shorter A., Jesus and the Witchdoctor. An Approach to Healing and Wholeness, London: Geoffrey Chapman - Maryknoll: Orbis Books, 1985.

Smith A., Walking in Balance. The Spirituality-Liberation Praxis of Native Women, in: Native American Religious Identity. Unforgotten Gods, ed. J. Weaver, Maryknoll: Orbis Books, 1998, p. $178-198$.

Stolzman W., The Pipe and Christ. A Christian-Sioux Dialogue, Chamberlain, South Dakota: Tipi Press, 1986.

Tinker G., American Indian Liberation. A Theology of Sovereignty, Maryknoll: Orbis Books, 2008.

The Crossing of Two Roads. Being Catholic and Native in the United States, ed. M. Th. Archambault, M. Thiel, Ch. Vecsey, Maryknoll: Orbis Books, 2003.

Vecsey Ch., Traditional Ojibwa Religion and Its Historical Changes, Philadelphia: The American Philosophical Society, 1983.

Weaver J., From I-Hermeneutics to We-Hermeneutics, in: Native American Religious Identity. Sources and Interpretations, ed. S. Gill, Delmont: Wadsworth Publications, 1983, p. 1-25. 
AChiel Peelman - member of the Missionary Oblates of Mary Immaculate. Full time professor of the Faculty of theology and former Academic Vice-Rector at Saint Paul University in Ottawa (Canada). He has written extensively on inculturation and contemporary contextual theology. His recent publications include: Native American Spirituality and Christianity, in: The Wiley-Blackwell Companion to Inter-Religious Dialogue, ed. C. Cornille, Hoboken (New Jersey): John Wiley \& Sons Ltd., 2013, p. 346-359. 